\title{
Sewage sludge composted in the coloring and development of Bermuda grass
}

\author{
Brian Turati Rezende ${ }^{1}\left(\right.$ P) Patrick Luan Ferreira dos Santos ${ }^{2 *}$ (), Jéssica Cristina Meira Bezerra ${ }^{1}$, \\ Maximiliano Kawahata Pagliarini ${ }^{3}$ (), Regina Maria Monteiro de Castilho $^{1} \mathbb{C D}^{\mathbb{C}}$ \\ ${ }^{1}$ Universidade Estadual Paulista (UNESP), Faculdade de Engenharia de Ilha Solteira, Ilha Solteira-SP, Brazil \\ ${ }^{2}$ Universidade Estadual Paulista (UNESP), Faculdade de Ciências Agronômicas, Botucatu-SP, Brazil \\ ${ }^{3}$ Universidade Federal da Grande Dourados, Fazenda Experimental de Ciências Agrárias, Dourados-MS, Brazil
}

\begin{abstract}
'Barazur' or Discovery ${ }^{\mathrm{TM}}$ (Cynodon dactylon) is a new variety of Bermuda grass that has slow vertical growth and a bluish-green colour, and the use of sewage sludge in implantation of this species may be an alternative for its sustainable cultivation, without need for chemical fertilizers. Thus, the objective was to evaluate the influence of sewage sludge compound on colour and development of Bermuda grass Discovery ${ }^{\mathrm{TM}}$. The experiment was conducted in the field with sod implanted in black plastic containers (volume 8.46 L) filled with soil + sand (1:1) and added different dosages of sludge compost, being: $0 \mathrm{~g} \mathrm{~L}^{-1}$ (control), $30 \mathrm{~g} \mathrm{~L}^{-1}, 60 \mathrm{~g} \mathrm{~L}^{-1}$ and $120 \mathrm{~g} \mathrm{~L}^{-1}$. Digital image analysis, fresh and dry leaf mass, Nitrogen leaf and Nitrogen leaf accumulation were evaluated. It was observed that the sewage sludge influenced on turfgrass colouring and development, where $30 \mathrm{~g} \mathrm{~L}^{-1}$ showed excellent results for colouring with less mass production and $\mathrm{N}$ accumulation than the highest dose, showing that this treatment is sufficient for lawn development, without the need of using higher concentrations of compound. It is concluded that the use of composted sewage sludge at a dose of $30 \mathrm{~g} \mathrm{~L}^{-1}$ is recommended for use in implantation of Bermuda grass Discovery ${ }^{\mathrm{TM}}$.
\end{abstract}

Keywords: Cynodon dactylon, ornamental lawn, organic fertilization, aesthetic quality.

\section{Resumo}

Composto de lodo de esgoto na coloração e desenvolvimento da grama bermuda

'Barazur' ou Discovery ${ }^{\mathrm{TM}}$ (Cynodon dactylon) é uma nova variedade de grama bermuda que apresenta lento crescimento vertical e coloração verde-azulada, sendo que o uso de lodo de esgoto na implantação dessa espécie pode ser uma alternativa para seu cultivo sustentável, sem necessidade de uso de fertilizantes químicos. Assim, objetivou-se avaliar a influência do composto de lodo de esgoto na coloração e desenvolvimento da grama bermuda Discovery ${ }^{\mathrm{TM}}$. O experimento foi conduzido a campo com tapetes de grama implantados em recipientes de plástico preto (volume 8,46 L) preenchidos com solo + areia $(1: 1)$ e adicionado diferentes dosagens de composto de lodo, sendo eles: $0 \mathrm{~g} \mathrm{~L}^{-1}$ (testemunha), $30 \mathrm{~g} \mathrm{~L}^{-1}, 60 \mathrm{~g} \mathrm{~L}^{-1}$ e $120 \mathrm{~g} \mathrm{~L}^{-1}$. Avaliou-se análise por imagem digital, massa fresca e seca das folhas, $\mathrm{N}$ foliar e acúmulo de $\mathrm{N}$ nas folhas. Observou-se que o lodo de esgoto influenciou na coloração $\mathrm{e}$ desenvolvimento do gramado, onde $30 \mathrm{~g} \mathrm{~L}^{-1}$ apresentou excelentes resultados para coloração e sua produção de massa e acúmulo de $\mathrm{N}$ foi menor que a maior dose, mostrando que essa dose já é suficiente para desenvolvimento do gramado, sem necessidade de uso de maiores concentrações do composto. Conclui-se que o uso de lodo de esgoto compostodo na dose de $30 \mathrm{~g} \mathrm{~L}^{-1}$ é recomendado para uso na implantação de grama bermuda Discovery ${ }^{\mathrm{TM}}$.

Palavras-chave: Cynodon dactylon, gramado ornamental, adubação orgânica, qualidade estética.

\section{Introduction}

During the last few years, ornamental lawns have assumed a prominent place in the world, mainly due to their admirable aesthetic value (Oliveira et al., 2018). In this way, visual aspect, such as the intense green colour and density (closed lawn, without flaws) is vitally important for acceptance and choice of species to be implanted (Gazola et al., 2016; Santos et al., 2019).

In Brazil, the most cultivated and used grass for ornamental purposes is Zoysia grass (Zoysia japonica) (Godoy et al., 2012). However, due to great market

*Corresponding author: patricklfsantos@gmail.com

https://doi.org/10.1590/2447-536X.v26i3.2204

Received Jun 15, 2020 | Accepted Aug 02, 2020| Available online Aug 14, 2020

Licensed by CC BY 4.0 (https://creativecommons.org/licenses/by/4.0/)

Area Editor: Ana Maria Mapeli 
availability of new varieties, landscapers have been looking for alternative species to complement projects, mix shades of green and that require little maintenance (Souza et al., 2016; Souza et al., 2020; Qually Grama, 2020).

Aiming this need, Discovery ${ }^{\mathrm{TM}}$ (or 'Barazur') is a new variety of Bermuda grass (Cynodon dactylon) (Bruijn, 2012; Khanal et al., 2017), recently launched in Brazil and has some specific characteristics. Its colouring is differentiated, presenting a bluish-green, which is attractive to ornamental sector; it has a slow growth rate, with pruning requirements $75 \%$ less than conventional Bermuda grass and 50\% less than Zoysia grass, which reduces maintenance costs. In addition, it has good cold tolerance and drought resistance, making it recommended for residential gardens, parks and commercial use (Qually Grama, 2020). By current scenario of sustainable cultivation, issues related to the use of organic compounds in lawns have become an alternative to mineral fertilization, especially the use of composted sewage sludge (Backes et al., 2017).

The installations of Sewage Treatment Plants (STPs) have proven to be a viable alternative to reduce environmental impact on water bodies in large cities. However, with population growth of urban centres, the generation of sewage sludge has increased considerably, compelling sanitation companies and authorities to search for alternatives for its use, as the disposal of sludge in landfills represents between $30 \%$ and $40 \%$ operating costs of sanitation companies (Gomes et al., 2017).

Thus, the use of sanitized sewage sludge has been an alternative, as this is a solid residue with high content of organic matter and considerable levels of macro and micronutrients that enable improvement of soil physical and chemical properties resulting in an agricultural input of good quality (Godoy et al., 2012; Backes et al., 2017; Mota et al., 2019). Due to its high nitrogen content (2-3\%), it provides greater development for lawn, increasing green colour, resistance and soil cover rate (Godoy et al., 2012;
Mota et al., 2019). However, the resolution of the National Environment Council - CONAMA n ${ }^{\circ}$. 375/2006 (Conama, 2006) prohibits the use of sludge in crops whose edible part is in contact with the soil, being an option for turfgrass areas.

Nobili et al. (2014) obtained good responses for development of Bermuda grass with application of sewage sludge, and proved to be an alternative for waste disposal, as it fulfils environmental and economic requirements. Mota et al. (2019) in work with sewage sludge in Zoysia grass observed that it provided an adequate supply of nutrients to lawn, when applied in a single dose of $30 \mathrm{Mg}$ $\mathrm{ha}^{-1}$. However, there are no indications of the best dose to be used in each cultivar of grass, so it is necessary to obtain research to supply this demand. Thus, the objective was to evaluate the influence of sewage sludge compound on colour and development of Bermuda grass Discovery ${ }^{\mathrm{TM}}$.

\section{Material and methods}

The experiment was performed in full sun, in an experimental area, in the Northwest region of São Paulo state from May to August 2019. According to the Köppen classification, the climate of region is Aw type, characterized by rainy season in summer and dry in winter, defined as tropical humid. During evaluation period the mean temperature was $24.1{ }^{\circ} \mathrm{C}$, with mean relative humidity of $64.15 \%$ and accumulated precipitation of $67.5 \mathrm{~mm}$.

For experiment installation, Discovery ${ }^{\mathrm{TM}}$ Bermuda grass was acquired in rug form, cut and implanted in black polyethylene containers $(47.5 \mathrm{~cm} \times 17.5 \mathrm{~cm}$ of top part, $41.5 \mathrm{~cm} \mathrm{x} 11.3 \mathrm{~cm}$ of bottom, $15.5 \mathrm{~cm}$ of height, 8.46 L of volume). They were filled with soil + sand (1:1) as substrate and added sewage sludge organic compost (when preparing the substrate) coming from a treatment station from the interior of São Paulo state. The chemical analysis of compost was shown in Table 1.

Table 1. Chemical analysis of sewage sludge.

\begin{tabular}{|c|c|c|c|c|c|c|c|c|}
\hline $\mathbf{N}$ & $\mathbf{P}_{2} \mathbf{O}_{5}$ & $\mathbf{K}_{2} \mathrm{O}$ & $\mathrm{Ca}$ & Mg & $\mathbf{S}$ & Humidity & O.M. & O.C \\
\hline \multicolumn{6}{|c|}{ 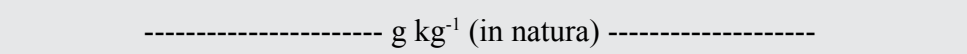 } & $\%$ & $\mathrm{~g} \mathrm{~kg}^{-1}$ & dry \\
\hline 28 & 35 & 1.0 & 15 & 4.0 & 4.0 & 21 & 370 & 260 \\
\hline $\mathrm{Na}$ & B & $\mathrm{Cu}$ & $\mathrm{Fe}$ & $\mathrm{Mn}$ & $\mathrm{Zn}$ & $\mathrm{C} / \mathrm{N}$ & \multicolumn{2}{|c|}{$\mathrm{pH}$} \\
\hline \multicolumn{6}{|c|}{ 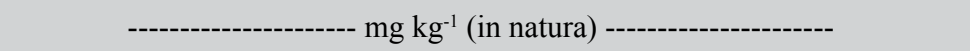 } & & \multicolumn{2}{|c|}{ in natura } \\
\hline 1,132 & 145 & 185 & 33,793 & 259 & 701 & $7 / 1$ & \multicolumn{2}{|c|}{5.8} \\
\hline
\end{tabular}

O.M. - Organic matter, O.C. - organic carbon

The Treatments were defined by dosages of sludge compound, being: $0 \mathrm{~g} \mathrm{~L}^{-1}$ (control), $30 \mathrm{~g} \mathrm{~L}^{-1}, 60 \mathrm{~g} \mathrm{~L}^{-1}$ and $120 \mathrm{~g} \mathrm{~L}^{-1}$ (corresponding to application in $0,0.84,1.68$, $3.36 \mathrm{~g} \mathrm{~N} \mathrm{~L}^{-1}$, respectively). The experimental design used was completely randomized with 5 replicates. Irrigation management was daily until substrate saturation, in order to ensure that the water factor did not interfere in the results.

On July $3^{\text {th }} 2019$ (45 days after installation), photographs of the area were taken with a $13 \mathrm{Mp}$ camera at a distance of $1 \mathrm{~m}$. The images were transferred to a computer and by 
Adobe Fireworks ${ }^{\mathrm{TM}}$ program RGB value (Red, Green and Blue) were generated.

As only green $(\mathrm{G})$ component does not define green colour, depending also on red (R) and blue (B) components, the results were compiled into an electronic spreadsheet in MS Excel ${ }^{\mathrm{TM}}$ and converted to HSB (hue, saturation and brightness), according to the methodology described by Godoy et al. (2012).

After obtaining HSB values, Dark Green Colour Index (DGCI) was calculated according methodology cited by Karcher and Richardson (2003). Through RGB values found, it was possible to identify the colour code, given by the hexadecimal colour system. This format is characterized by the code \#RRGGBB, where RR is the value of red (using two hexadecimal digits), GG is the value of green and BB the value of blue, and the codes vary from 00 to FF

Fresh and dry mass of leaves was collected after cutting 97 days after installation. The cut is carried out with scissors, manually, and the every leaves are removed from each treatment, and were packed in identified paper bags and weighed to determine fresh mass. And after allocating the samples in an oven at $60{ }^{\circ} \mathrm{C}$ for $72 \mathrm{~h}$, the dry mass was determined.

The nutritional analysis of nitrogen leaf was according to methodology of Malavolta et al. (1997) and later it was multiplied by dry mass to obtain the accumulation of nutrient in leaves.

The data were submitted to analysis of variance ( $\mathrm{F}$ test), at 5\% significance level. When relevant, the means were compared with the Tukey test at 5\% significance or probability, using Sisvar program for data analysis (Ferreira, 2019), and Pearson's correlation analysis between variables was performed.

\section{Results and discussion}

The results indicate that there was significant difference ( 1 and 5\%) for all traits assessed by digital image analysis (Table 2), showing that doses of sewage sludge influenced the colour of Bermuda grass Discovery ${ }^{\mathrm{TM}}$.

As each of three primary colours (RGB) may have values from 0 to 255 (256 probable results), the combination of them results in $16,777,216$ of possible colours (Lima et al., 2012), with each component stands out in greater result depends on the main primary colour. In the present study, among RGB results, green showed higher values, followed by blue and lastly red, thus indicating that lawn is more bluish-green in colour, regardless of sludge dose used.

However, the value for green component was higher for control, differing from all other treatments, where $120 \mathrm{~g} \mathrm{~L}^{-1}$ showed the lowest index. In this case, only green component does not present the actual lawn colour, depending also on values of blue and red (Godoy et al., 2012). Thus, the analysis by digital image only for the RGB values is not well represented, depending on the other variables of HSB colour system, as also observed by Gazola et al. (2016) in colour evaluation in Zoysia grass.

Table 2. Analysis by digital image of Bermuda grass Discovery ${ }^{\mathrm{TM}}$ as a function of concentrations of sewage sludge composted in substrate. R: Red, G: Green, B: Blue, DGCI: Dark Green Colour Index.

\begin{tabular}{|c|c|c|c|c|c|c|c|}
\hline \multirow{2}{*}{ Treatments } & $\mathbf{R}$ & G & B & \multirow{2}{*}{$\begin{array}{l}\text { Hue } \\
\left({ }^{\circ}\right)\end{array}$} & Saturation & Brightness & \multirow{2}{*}{\begin{tabular}{|l} 
DGCI \\
Admin
\end{tabular}} \\
\hline & \multicolumn{3}{|c|}{----------- Admin. --------- } & & \multicolumn{2}{|c|}{-------- \% --------- } & \\
\hline $0 \mathrm{~g} \mathrm{~L}^{-1}$ & $105 \mathrm{a}$ & $169 \mathrm{a}$ & $136 \mathrm{a}$ & $149 \mathrm{~b}$ & $38.16 \mathrm{~b}$ & $66.28 \mathrm{a}$ & $0.82 \mathrm{~b}$ \\
\hline $30 \mathrm{~g} \mathrm{~L}^{-1}$ & $52 \mathrm{~b}$ & $128 \mathrm{~b}$ & $97 \mathrm{~b}$ & $155 \mathrm{a}$ & $59.73 \mathrm{a}$ & $50.20 \mathrm{~b}$ & $0.83 \mathrm{ab}$ \\
\hline $60 \mathrm{~g} \mathrm{~L}^{-1}$ & $51 \mathrm{~b}$ & $106 \mathrm{c}$ & $80 \mathrm{~b}$ & $153 \mathrm{ab}$ & $56.17 \mathrm{a}$ & $41.57 \mathrm{c}$ & $0.86 \mathrm{a}$ \\
\hline $120 \mathrm{~g} \mathrm{~L}^{-1}$ & $47 \mathrm{~b}$ & $121 \mathrm{bc}$ & $94 \mathrm{~b}$ & $157 \mathrm{a}$ & $58.75 \mathrm{a}$ & $47.35 \mathrm{bc}$ & $0.85 \mathrm{ab}$ \\
\hline $\mathrm{CVC}$ & 20 & 21 & 23 & 5 & 10.58 & 8.04 & 0.04 \\
\hline CV $(\%)$ & 20.23 & 10.16 & 14.94 & 2.11 & 12.91 & 10.16 & 2.82 \\
\hline $\mathrm{F}$ & $17.94 * *$ & $16.44^{* *}$ & $10.25 * *$ & $3.64 *$ & $8.71 * *$ & $16.44 * *$ & $2.62 * *$ \\
\hline
\end{tabular}

Averages followed by the same letter in the column does not differ by Tukey test ( $p>0.05$ ). CVC - Critical Value for comparison. CV - coefficient of variation. ** - significant at $1 \%$ by the $\mathrm{F}$ test; * significant at $5 \%$ by the $\mathrm{F}$ test.

The hue shows monochromatic colour, expressing pigment in a number between $0^{\circ}$ and $360^{\circ}$ (Figure 1), essentially an angle around the chromatic circle, and so depending on the angle, a colour variable (like a rainbow) is expressed that varies from red $\left(0^{\circ}\right)$, yellow $\left(60^{\circ}\right)$, green $\left(120^{\circ}\right)$, cyan $\left(180^{\circ}\right)$, blue $\left(240^{\circ}\right)$ and magenta $\left(300^{\circ}\right)$ (Godoy et al., 2012).

Lawn studies indicate hue results ranging from 60 to $120^{\circ}$, where closer to $120^{\circ}$ the lawn is greener intense, while closer to $60^{\circ}$ more yellow (Backes et al., 2010; Lima et al., 2012; Gazola et al., 2016). These values are related to grass nutrition, as in adequate fertilization program lawn has an intense green colour and a yellowish-green when deficient (Godoy et al., 2012). However, in the present study, the values ranged from $149^{\circ}$ to $157^{\circ}$, above the maximum for green $\left(120^{\circ}\right)$, thus indicating that Bermuda grass has a different coloration in relation to other species, being in a scale from green $\left(120^{\circ}\right)$ to cyan $\left(180^{\circ}\right)$. The result corroborates with the description of being a dark blue-green coloured lawn, which was portrayed through an RHS colour chart of the Royal Horticultural Society of London (Bruijn, 2012). 


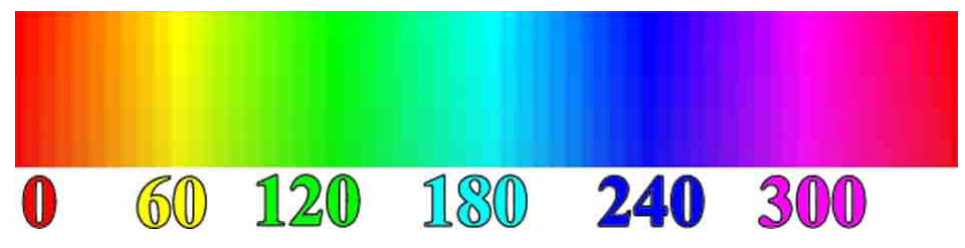

Figure 1. Hue values: red $\left(0^{\circ}\right)$, yellow $\left(60^{\circ}\right)$, green $\left(120^{\circ}\right)$, cyan $\left(180^{\circ}\right)$, blue $\left(240^{\circ}\right)$ and magenta $\left(300^{\circ}\right)$.

Values close to $60^{\circ}$ present more yellowish colour of lawn, as previously described, which is not aesthetically pleasing for ornamental species (Gazola et al., 2016). However, in the present study, no treatment presented this result, indicating that control, which had the lowest value $\left(149^{\circ}\right)$, is possibly well nourished, and this variable can be an excellent option for estimating grass nutritional status. Backes et al. (2010) in an experiment with sewage sludge in Zoysia grass, concluded that the hue may serve as an index to assist in fertilization recommendation. Agati et al. (2015) also observed a good relationship between hue of Zoysia grass 'Tifway 419' and N doses, where the gradual increase of the nutrient provided higher hue values.

Regarding saturation, significant difference was observed, where only treatment that received no dose of sludge $\left(0 \mathrm{~g} \mathrm{~L}^{-1}\right)$ showed lower result and differed from all other treatments. According to Godoy et al. (2012), saturation shows how vivid (or intense) the resulting colour will be, ranging from $0 \%$ to $100 \%$, where $100 \%$ saturated colour will be vivid and strong, whereas $50 \%$ colour will be more subtle tone and a desaturated colour will be more greyish. Thus, in the present study, doses from $30 \mathrm{~g} \mathrm{~L}^{-1}$ of sewage sludge are sufficient to provide greater vivacity or greenness to the lawn.

Brightness (also called value), describes how light or dark resemble a colour, and refers to the amount of perceived light and is also measured in a percentage from 0 to 100 , where the higher percentage, the greater the brightness of colour (Godoy et al., 2012). Thus, $0 \%$ would be completely black and $100 \%$ completely white. As a result, a lawn that has green colour, when mixed with white, results in a lighter green, and when mixed with black, darker green, thus denominating the colour tone (Backes et al., 2010; Lima et al., 2012; Gazola et al., 2016). The results of the present study showed that sludge positively influenced the brightness of the Bermuda grass Discovery ${ }^{\mathrm{TM}}$, where control differed from all other treatments, and presented lighter shade, while 60 and $120 \mathrm{~g} \mathrm{~L}^{-1}$ doses are statistically equal showing darker shade, which can be widely desired for ornamental lawns

For DGCI it is possible to observe the influences of alterations in lawn visual quality, where control presented lower index. This variable was essential to prove that the compost when used, accurately reflected the dark green of lawn. Higher DGCI values reflected more intense colour, which is aesthetically pleasing (Lima et al., 2012; Gazola et al., 2016).

The results of DGCI (Table 2) were above the adequate value (0.63) for Bermuda grass mentioned by Godoy et al. (2012). This is due to sewage sludge presenting $2.8 \%$ $\mathrm{N}\left(28 \mathrm{~g} \mathrm{Kg}^{-1}\right)$ in its composition, and thus higher doses were able to provide higher concentrations of the element to the substrate (where 60 and $120 \mathrm{~g} \mathrm{~L}^{-1}$, contained 1.68 and $3.36 \mathrm{~g} \mathrm{~N} \mathrm{~L}^{-1}$ respectively). According to Gazola et al. (2016), $\mathrm{N}$ is the nutrient required in greater quantities by turfgrass, being mainly part of chlorophyll molecules, which for Taiz et al. (2017), are composed of a central atom, composed by magnesium and linked to four others nitrogen. Therefore, higher its concentration, greener the lawn will be (Godoy et al., 2012; Santos et al., 2019). Thus, there is a correlation between chlorophylls and lawn nutrition (Santos and Castilho, 2015; Oliveira et al., 2018; Santos et al., 2019), implying that in the present study, treatments that received doses of sewage sludge are better nourished than control.

Thus, experiments with digital image analysis are efficient to estimate the nutritional status of the lawn (Zhang et al., 2017), especially with regard to nitrogen, and corroborate the studies that correlate this analysis with nitrogen doses by Backes et al. (2010), Lima et al. (2012), Agati et al. (2015) and Gazola et al. (2016).

As the doses of sewage sludge had an influence on lawn colour (Table 2), the visual aspect might be evident, where the images demonstrate this result (Figure 2).

The photos show the exact colour found in each treatment, as well as the colour code generated. The values observed in Figure 2, one of the more 16 million colours available, described previously and are expressed in hexadecimal form. Thus, in the present study, the generated codes are the combination of the RGB components found in Table 2 , and it is evident that even presenting visually similar colours, they differ with the sewage sludge concentrations, where control was the only one to present a visually lighter blueish-green colour than the other treatments (Figure 2). 

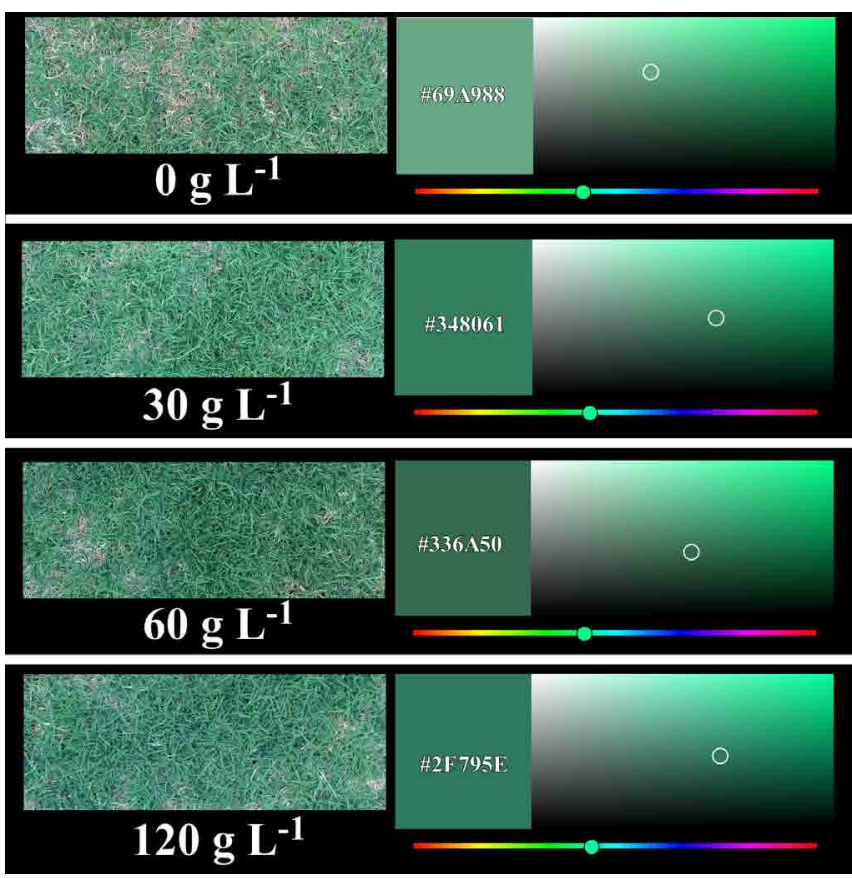

Figure 2. Visual aspect of Bermuda grass Discovery ${ }^{\mathrm{TM}}$ due to the use of sewage sludge doses and colouring found with its respective code.

The results of lawn growth showed that only nitrogen content did not present statistical difference between the evaluations (Table 3). For fresh and dry mass with the increase of the sludge doses, an increase in the mass production was observed, where $120 \mathrm{~g} \mathrm{~L}^{-1}$ presented the highest value for two analysed variables, while the control the lowest result. Sludge, as it is composed of a high content of $\mathrm{N}\left(28 \mathrm{~g} \mathrm{Kg}^{-1}\right)$ (Table 1) (Godoy et al., 2012), caused higher concentrations of this nutrient to stimulate grass vegetative growth (Taiz et al., 2017; Zhang et al., 2018). However, the greater the amount of mass produced, the greater the cost for cutting maintenance, with expenses for machinery, operators and fuel (Santos et al., 2016).

The effect of sewage sludge doses increasing on mass production was also observed in works with Bermuda grass performed by Nobili et al. (2014) and Zoysia grass by Backes et al. (2017) and Mota et al. (2019). However, the values found in the present study are lower than the mass produced by experiments in Bermuda grass 'Celebration' (Lima et al., 2015), 'Tifdawarf' (Agnihotri et al., 2017) and 'Tifway 419' (Santos and Castilho, 2018), corroborating to theis description of having slow growth (Qually Grama, 2020) and consequently low need of maintenance.

Table 3. Fresh and dry mass and leaf nitrogen content and accumulation in Bermuda grass Discovery ${ }^{\mathrm{TM}}$ as function of sewage sludge concentrations composted in the substrate.

\begin{tabular}{|c|c|c|c|c|}
\hline Treatments & $\begin{array}{c}\text { Fresh mass } \\
\mathrm{g} \mathrm{m}^{-2}\end{array}$ & $\begin{array}{l}\text { Dry mass } \\
\text { g m }^{-2}\end{array}$ & $\begin{array}{l}\text { Nitrogen } \\
\mathrm{g} \mathrm{Kg}^{-1}\end{array}$ & $\begin{array}{l}\text { Accumulated nitrogen } \\
\qquad \mathrm{g} \mathrm{N} \mathrm{m}^{-2}\end{array}$ \\
\hline $0 \mathrm{~g} \mathrm{~L}^{-1}$ & $505.5 \mathrm{c}$ & $297.9 \mathrm{~b}$ & $15.5 \mathrm{a}$ & $4.6 \mathrm{~b}$ \\
\hline $30 \mathrm{~g} \mathrm{~L}^{-1}$ & $716.6 \mathrm{bc}$ & $385.9 \mathrm{ab}$ & $15.2 \mathrm{a}$ & $5.8 \mathrm{ab}$ \\
\hline $60 \mathrm{~g} \mathrm{~L}^{-1}$ & $940.5 \mathrm{ab}$ & $498.9 \mathrm{ab}$ & $14.7 \mathrm{a}$ & $7.4 a b$ \\
\hline $120 \mathrm{~g} \mathrm{~L}^{-1}$ & $1127.2 \mathrm{a}$ & $569.3 \mathrm{a}$ & $14.2 \mathrm{a}$ & $8.0 \mathrm{a}$ \\
\hline CVC & 337.2 & 210.8 & 3.4 & 2.9 \\
\hline CV (\%) & 15.69 & 18.41 & 8.67 & 16.95 \\
\hline $\mathrm{F}$ & $13.13^{* *}$ & $6.65^{*}$ & $0.61^{\mathrm{ns}}$ & $6.10^{*}$ \\
\hline
\end{tabular}

Averages followed by the same letter in the column does not differ by Tukey test $(\mathrm{p}>0.05)$. Averages followed by the same letter in the column does not differ by Tukey test $(\mathrm{p}>0.05)$. CVC - Critical Value for comparison. $\mathrm{CV}$ - coefficient of variation. ** - significant at $1 \%$ by the $\mathrm{F}$ test; * significant at $5 \%$ by the $\mathrm{F}$ test. 
For leaves $\mathrm{N}$ content, no statistically significant difference was observed (Table 3 ). However, the results are well below the range recommended by Godoy et al. (2012) who stated that levels below $18 \mathrm{~g} \mathrm{~kg}^{-1}$ indicate critical $\mathrm{N}$ deficiency in Bermuda grass. The values found are outside what was observed by Lima et. al. (2010), in work with the production of Bermuda grass 'Celebration' (22 - $41 \mathrm{~g}$ $\mathrm{kg}^{-1}$ of dry mass), but within what was found by Nobili et al. (2014) also for Bermuda grass fertilized with sewage sludge (8.5 to $11.6 \mathrm{~g} \mathrm{~kg}^{-1}$ of dry mass). It is essential to state that the species of present study is a new variety, with different colour, and may have different nutritional requirements, as doses of sewage sludge provided excellent development of lawn, inferring that the results found may be adequate for the species.

However, as previously described, leaf $\mathrm{N}$ concentrations did not show statistical difference, thus, these values may be related to nutrient dilution through greater growth (Lima et al., 2012), given the mass values produced.

With higher concentrations of sludge, greater accumulation of nitrogen was observed, where $120 \mathrm{~g} \mathrm{~L}^{-1}$ found the highest value and differs only from control.
However, for ornamental lawns, it is essential to find the dose that provides a good accumulation of nitrogen, with less mass production and that provides intense green colour. Like this, $30 \mathrm{~g} \mathrm{~L}^{-1}$ has these characteristics, as it presented an excellent DGCI (0.83) and its mass production and $\mathrm{N}$ accumulation was lower than the highest dose (Table 3). Thus, this dose would be enough for the development of the lawn, without the need to use higher compost concentrations.

The correlation found between the variables analysed showed interesting results. Foliar $\mathrm{N}$ showed a negative correlation with fresh and dry mass, that is, the greater the mass produced, the lower the value of $\mathrm{N}$ (Table 4), corroborating what was observed in the present study (Table 3). However, there was an opposite effect on the $\mathrm{N}$ accumulation with the same FM and DM. The DCGI correlated only with the hue of the lawn, showing no correlation between foliar $\mathrm{N}$, which is the main nutrient that gives green colour to the grasses, as previously described. The three RGB components showed a high and positive correlation, since one depends on the other to check the characteristic colour combination of the turfgrass.

Table 4. Pearson's correlation coefficient between the variables analysed

\begin{tabular}{|c|c|c|c|c|c|c|c|c|c|c|}
\hline & $\mathbf{R}$ & G & B & Hue & Sat. & Brig. & DGCI & FM & DM & $\mathbf{N}$ \\
\hline G & $0.96^{* *}$ & & & & & & & & & \\
\hline B & $0.97 * *$ & $0.98^{* *}$ & & & & & & & & \\
\hline Hue & $-0.27^{\mathrm{ns}}$ & $-0.25^{\text {ns }}$ & $-0.12^{\mathrm{ns}}$ & & & & & & & \\
\hline Sat. & $-0.97^{* *}$ & $-0.89^{* *}$ & $-0.93^{* *}$ & $0.21^{\mathrm{ns}}$ & & & & & & \\
\hline Brig. & $0.96^{* *}$ & $1.00 * *$ & $0.98^{* *}$ & $-0.25^{\mathrm{ns}}$ & $-0.89^{* *}$ & & & & & \\
\hline DGCI & $0.02^{\mathrm{ns}}$ & $-0.11^{\mathrm{ns}}$ & $0.04^{\mathrm{ns}}$ & $0.72 * *$ & $-0.20^{\mathrm{ns}}$ & $-0.11^{\text {ns }}$ & & & & \\
\hline FM & $-0.69 * *$ & $-0.72 * *$ & $-0.65^{*}$ & $0.53^{\mathrm{ns}}$ & $0.63^{*}$ & $-0.72 * *$ & $0.36^{\mathrm{ns}}$ & & & \\
\hline DM & $-0.64 *$ & $-0.66^{*}$ & $-0.61^{*}$ & $0.46^{\mathrm{ns}}$ & $0.58^{*}$ & $-0.66^{*}$ & $0.31^{\text {ns }}$ & $0.97^{* *}$ & & \\
\hline $\mathrm{N}$ & $0.23^{\text {ns }}$ & $0.22^{\mathrm{ns}}$ & $0.22^{\mathrm{ns}}$ & $-0.09^{\text {ns }}$ & $-0.23^{\text {ns }}$ & $0.22^{\mathrm{ns}}$ & $-0.01^{\text {ns }}$ & $-0.56^{*}$ & $-0.58^{*}$ & \\
\hline Acc. $\mathrm{N}$ & $-0.65^{*}$ & $-0.68 * *$ & $-0.63^{*}$ & $0.47^{\text {ns }}$ & $0.59 *$ & $-0.68 * *$ & $0.33^{\text {ns }}$ & $0.94^{* *}$ & $0.96^{* *}$ & $-0.38^{\text {ns }}$ \\
\hline
\end{tabular}

** - significant at $1 \%$ by the Pearson's test, * significant at $5 \%$ by the Pearson's test. ns- not significant. R - Red, G- Green, B- Blue, DGCI- Dark Green Colour Index, Sat- Saturation, Brig- Brightness, FM- Fresh mass, DM- Dry mass, N- Nitrogen, Acc. N- Accumulated nitrogen.

In summary, the results demonstrated that there was an effect of the use of composted sewage sludge on the colour and development of the Discovery ${ }^{\mathrm{TM}}$ Bermuda grass. The increase in doses provided greater fresh and dry mass and accumulated $\mathrm{N}$, while the colouring performed by digital analysis, demonstrated that from the concentration of $30 \mathrm{~g}$ $\mathrm{L}^{-1}$ it is already sufficient to demonstrate the characteristic colour of the turfgrass.

\section{Conclusions}

The composted sewage sludge positively influenced the colour and development of the lawn, giving the bluish green characteristic of Discovery ${ }^{\mathrm{TM}}$ Bermuda grass. The use of $30 \mathrm{~g} \mathrm{~L}^{-1}$ of composted sewage sludge is recommended as fertilization to Bermuda grass Discovery ${ }^{\mathrm{TM}}$ implantation. Doses greater than $30 \mathrm{~g} \mathrm{~L}^{-1}$ of sewage sludge increase mass production, which is not a desired result to maintain the aesthetics of the lawn.

\section{Author Contribution}

B.T.R.: Idea of the experiment, field analysis, data collection and analysis, interpretation of data. P.L.F.S.: Idea of the experiment, critical review, analysis and interpretation of data, approval of the final version. J.C.M.B.: Field analysis, data collection and analysis. M.K.P.: Critical review and translation. R.M.M.C.: Critical review, analysis and interpretation of data, approval of the final version, work advisor. 


\section{Acknowledgements}

The authors are grateful to the Faculdade de Ciências Agronômicas (UNESP) Botucatu-SP, for the collaboration to carry out the experiment.

\section{References}

AGATI, G.; FOSCHI, L.; GROSSI, N.; VOLTERRANI, M. In field non-invasive sensing of the nitrogen status in hybrid bermudagrass (Cynodon dactylon $\times C$. transvaalensis Burtt Davy) by a fluorescence-based method. European Journal of Agronomy, v.63, p.89-96, 2015. DOI: https:// doi.org/10.1016/j.eja.2014.11.007

AGNIHOTRI, R.; CHAWLA, S.L.; PATIL, S. Evaluation of warm season turfgrasses for various qualitative and quantitative traits under Gujarat agro-climatic conditions. Indian Journal of Agricultural Sciences, v.87, n.7, p. 8391, 2017.

BACKES, C.; SANTOS, A.J.M.; GODOY, L.J.G.; VILLAS BÔAS, R. L.; RIBON, A. A.; BESSA, S. V. Efeito residual do lodo de esgoto e de manejos mecanizados na produção de tapetes e na extração de nutrientes pela grama esmeralda. Espacios, v.38, n.14, p. 3, 2017.

BACKES, C.; VILLAS BÔAS, R.L.V.; LIMA, C.P.L.; GODOY, L.J.G.; BÜLL, L.T.; SANTOS, A.J.M. Estado nutricional em nitrogênio da grama esmeralda avaliado por meio do teor foliar, clorofilômetro e imagem digital, em área adubada com lodo de esgoto. Bragantia, v.69, n.3, p.661-668, 2010. DOI: https://doi.org/10.1590/S000687052010000300018

BRUIJN, J. Bermuda grass plant named barazur. United States Plant Patent. n. PP22,963. Washington, DC: U.S. Deposit: 15 Sept. 2011. Concession: 14 Aug. 2012. Available at: <https://patentimages.storage.googleapis. com/57/77/eb/2834ccbfb7de7d/USPP22963.pdf>. Accessed on: June $20^{\text {th }} 2019$

CONAMA. Conselho Nacional Do Meio Ambiente. Resolução Conama $\mathbf{N}^{\mathbf{0}}$ 375, de 29 de Agosto de 2006. Available at: <www.mma.conama.gov.br/conama> Acessed on Mar. 25 2020.

FERREIRA, D.F. SISVAR: A computer analysis system to fixed effects Split plot type designs. Revista Brasileira de Biometria, v.37, n.4, p.529-535, 2019. DOI: https://doi. org/10.28951/rbb.v37i4.450.

GAZOLA, R.P.D.; BUZETTI, S.; GAZOLA, R.N.; CASTILHO, R.M.M.; TEIXEIRA FILHO, M.C.M.; CELESTRINO, T.S.; DUPA, E. Nitrogen dose and type of herbicide used for growth regulation on the green coloration intensity of Emerald grass. Ciência Rural, v.46, n.6, p.984-990, 2016. DOI: http://dx.doi.org/10.1590/0103-8478cr20150276
GODOY, L.J.G.; VILLAS BÔAS, R.L.; BACKES, C.; SANTOS, A.J.M. Nutrição, Adubação e Calagem para produção de gramas. 1.ed. Botucatu: FEPAF, 2012. 146p.

GOMES, G.C.; FREITAS, T.C.; LUCAS, R.R.; MIURA, A.K.; SOUZA, L.P.; GUARINO, E.S.G.; CASCAIS, L.B. Espécies Vegetais Recomendadas para Cortinamento em Estações de Tratamento de Esgoto (ETEs) na Região Sul do Rio Grande do Sul. Pelotas: Embrapa Clima Temperado, 2017. 95p.

KARCHER, D.E., RICHARDSON, M.D. Quantifying turfgrass color using digital image análisis. Crop Science, v.43, p.943-951, 2003. DOI: https://doi.org/10.2135/ cropsci2003.9430

KHANAL, S.; SCHWARTZ, B.M.; KIM, C.; ADHIKARI, J.; RAINVILLE, L.K.; AUCKLAND, S.A.; PETERSON, A.H. Cross-taxon application of sugarcane EST-SSR to genetic diversity analysis of bermudagrass (Cynodon spp.). Genetic Resources and Crop Evolution, v.64, p.20592070, 2017. DOI: https://doi.org/10.1007/s10722-0170496-2

LIMA, C.P.; BACKES, C.; FERNANDES, D.M.; SANTOS, A.J.M.; GODOY, L.J.G.; VILLAS BÔAS, R.L. Uso de índices de refletância das folhas para o nível de nitrogênio em grama-bermuda. Ciência Rural, v.42, n.9, p.1568-1574, 2012. DOI: http://dx.doi.org/10.1590/S010384782012005000062

LIMA， C.P.; BACKES， C.; SANTOS， A.J.M.; FERNANDES, D.M.; VILLAS BÔAS, R.L.; OLIVEIRA, M.R. Quantidade de nutrientes extraídos pela grama bermuda em função de doses de nitrogênio. Bioscience Journal, v.31, n.5, p.1432-1440, 2015. DOI: https://doi. org/10.14393/BJ-v31n5a2015-21967

LIMA, C.P.; BACKES, C.; VILLAS BÔAS, R.L.; OLIVEIRA, M.R.; KIIHL, T.A.M.; FREITAG, E.E. Bermuda grass sod production as related to nitrogen rates. Revista Brasileira de Ciência do Solo, v.34, n.2, p.371-377, 2010. DOI: https://doi.org/10.1590/S010006832010000200010

MALAVOLTA, E.; VITTI, G.C.; OLIVEIRA, S.A. Avaliação do estado nutricional das plantas: princípios e aplicações. 2ed. Piracicaba: POTAFOS, 1997. 319 p.

MOTA, F.D.; VILLAS BÔAS, R.L.; MATEUS, C.M.D.; SILVA, T.B.G. Sewage sludge compost in zoysia grass sod production. Revista Ambiente \& Água, v.14, n.1, e2301, 2019. DOI: https://doi.org/10.4136/ambi-agua.2301

NOBILE, F.O.; NUNES, H.D.; NEVES, J.C. Doses de lodo de esgoto sobre o desenvolvimento da grama bermuda (Cynodon dactylon). Nucleus, v.11, n.2, 2014. DOI: http:// dx.doi.org/10.3738/1982.2278.1046 
OLIVEIRA, N.B.; OLIVEIRA, J.F.V.; SANTOS, P.L.F.; GAZOLA, R.P.D.; CASTILHO, R.M.M. Avaliação do estado nutricional de três gramados ornamentais em Ilha Solteira-SP: um estudo de caso. Revista LABVERDE, v.9, n.1, p.96-119, 2018. DOI: http://dx.doi.org/10.11606/ issn.2179-2275.v9i1p96-119

QUALLY GRAMA. Discovery Bermudagrass Less Mowing. 5p. Available at: <https:/www.quallygrama. com.br/grama-discovery-lancamento.pdf $>$. Acessed on Mar. $25^{\text {th }} 2020$.

SANTOS, P.L.F.; BARCELOS, J.P.Q.; CASTILHO, R.M.M. Diferentes substratos de um gramado ornamental para uso em telhados verdes. Periódico Técnico e Científico Cidades Verdes, v.4, n.10, p.81-94, 2016. DOI: http://dx.doi.org/10.17271/2317860441020161393

SANTOS, P.L.F.; CASTILHO, R.M.M. Relação entre teor de clorofila e nitrogênio foliar em grama esmeralda cultivada em substratos. Tecnologia \& Ciência Agropecuária, v.9, n.2, p.51-54, 2015.

SANTOS, P.L.F.; CASTILHO, R.M.M.; GAZOLA, R.P.D. Pigmentos fotossintéticos e sua correlação com nitrogênio e magnésio foliar em grama bermuda cultivada em substratos. Acta Iguazu, v.8, n.1, p.92-101, 2019.

SANTOS, P.L.F.; CASTILHO, R.M.M. Substrates in the development of a sports turfgrass "Tifton 419". Ornamental Horticulture, v.24, n.4, p.138-144, 2018. DOI: https://doi.org/10.14295/oh.v24i2.1155
SOUZA, F.H.D.; GUSMÃO, M.R.; CAVALLARI, M.M.; BARIONI JUNIOR, W. Characterization of the potential of native grasses for use as lawns. Ornamental Horticulture, v.26, n.1, p. 109-120, 2020. DOI: https://doi. org/10.1590/2447-536X.v26i1.2067

SOUZA, F.H.D.; GUSMÃO, M.R.; MATTA, F.P.; CASTRO, A.C.R.; MITTELMANN, A.; FÁVERO, A.P.; JANK, L. Atributos desejáveis para gramados a serem cultivados sob condições brasileiras: uma proposta. Ornamental Horticulture, v.22, n.2, p.154-165, 2016. DOI: https://doi.org/10.14295/oh.v22i2.841

TAIZ, L.; ZEIGER, E.; MÜLLER, I.M.; MURPHY, A. Fisiologia e desenvolvimento vegetal. 6. ed. Porto Alegre: Artmed, 2017. 858p.

ZHANG, B.; SHI, J.A.; GUO, H.L.; ZONG, J.Q.; LIU, J.X. Influence of leaf age, irrigation and fertilization on leaf tensile strength of Cynodon dactylon and Zoysia japonica. Grassland Science, v.64, n.2, p.91-99, 2018. DOI: https:// doi.org/10.1111/grs.12193

ZHANG, C.; PINNIX, G.D.; ZANGH, Z.; MILLER, G.L.; RUFTY, T.W. Evaluation of key methodology for digital image analysis of turfgrass color using open-source software. Crop Science, v.57, p.550-558, 2017. DOI: https://doi.org/10.2135/cropsci2016.04.0285 